\title{
Aethozooides uraniae, a new deep-sea genus and species of solitary bryozoan from the Mediterranean Sea, with a revision of the Aethozoidae
}

\author{
Thomas Schwaha $^{1}$ (D) J Joan M. Bernhard ${ }^{2}$ - Virginia P. Edgcomb ${ }^{2} \cdot$ M. Antonio Todaro ${ }^{3}$ \\ Received: 4 September 2018 /Revised: 19 February 2019 / Accepted: 20 February 2019 / Published online: 4 April 2019 \\ (C) The Author(s) 2019
}

\begin{abstract}
Bryozoa is a phylum of about 6000 extant species that are almost exclusively colonial. Few species of the uncalcified Gymnolaemata, the ctenostomes, however, show solitary forms that essentially consist of single zooids. Recently, several specimens of a solitary ctenostome bryozoan were encountered for the first time in the deep Mediterranean Sea, at the edge of an anoxic brine lake. Differences in size, tentacle number, and in the variability of cystid appendages set these specimens apart from all other known solitary species. Moreover, additional morphological autapomorphic traits suggest the erection of a novel genus to allocate the new species. Consequently, the new taxon Aethozooides gen. nov. is proposed in virtue of the general resemblance of the Mediterranean specimens with those of the genus Aethozoon Hayward, 1978. Aethozooides uraniae gen. et sp. nov. shows significant variability in the number and location of cystid appendages that range from two on the basal side to one or two on the zooid mid-peristomial position and/or, rarely, on the terminal frontal side. The polypide possesses a distinct, long tentacle crown always carrying 10 tentacles. The prominent retractor muscle consists of numerous bundles that, in contrast to other known gymnolaemates, attach not only to the lophophoral base but also to various parts of the gut. Distally, the aperture shows a set of four apertural muscles including four parieto-vaginal bands. Reviewing the state and diversity of solitary ctenostomes, we propose a revision of the family Aethozoidae to include the genera Franzenella d'Hondt, 1983, Aethozoon, Aethozooides, and two species currently affiliated to the genus Franzenella (F. monniotae and F. radicans) for which we erected the new taxon Solella gen. nov.
\end{abstract}

Keywords Ctenostomata $\cdot$ Lophophore $\cdot$ Cystid appendages $\cdot$ Arachnidioidea $\cdot$ Solella

This article is registered in ZooBank under: urn:lsid:zoobank.org:pub:94A736C8-1751-4441-9A01-3CEC7F8BEFAB Aethozooides g. nov. is registered in ZooBank under: urn:lsid:zoobank.org:act:62390678-EC02-43DF-B03B-7CBF67E0B0E3 Aethozooides uraniae sp. nov. is registered in ZooBank under: urn:lsid:zoobank.org:act:ECA69946-2213-4A32-B06B-E013DF661E95 Solella g. nov. is registered in ZooBank under: urn:lsid:zoobank.org:act:F7DABA7D-3F59-48FE-A94A-8F29318C54A0

Communicated by S. Kaiser

Thomas Schwaha

thomas.schwaha@univie.ac.at

1 Department of Integrative Zoology, University of Vienna, Althanstraße 14, 1090 Vienna, Austria

2 Geology \& Geophysics Department, Woods Hole Oceanographic Institution, Woods Hole, MA 02543, USA

3 Department of Life Sciences, University of Modena and Reggio Emilia, via G. Campi 213/d, 41125 Modena, Italy

\section{Introduction}

Bryozoa is a phylum of sessile, colonial suspension feeders that comprises over 6000 recent and at least 15,000 fossil species (Bock and Gordon 2013). Typical for almost all bryozoans is that they form colonies of iterated modules, so-called zooids, that form an interconnected colony or zoarium. Each zooid consists of a protective body wall, the cystid, and the soft-body parts, the polypide. The latter has a ciliated tentacle crown, the lophophore, a u-shaped gut and associated musculature and neuronal structures. Typical for all bryozoans is that they can retract their soft-tissues into the protective cystid via a prominent retractor muscle (Mukai et al. 1997).

Currently, three distinct classes are recognized in the phylum: the freshwater-inhabiting Phylactolaemata, the marine Stenolaemata, and the predominantly marine Gymnolaemata (Bock and Gordon 2013). The latter consists of the uncalcified Ctenostomata and the calcified Cheilostomata (Cheetham and 
Cook 1983, Todd 2000). Calcification of cystid walls occurred at least twice in bryozoans, once in Stenolaemata and a second time in the cheilostome Gymnolaemata (Ernst and Schäfer 2006). Bryozoans colonize predominantely hard substrates but can also be found as specialized forms on soft substrates (e.g., Hirose 2011) or even as motile colonies (e.g., Cook 1988 ). In the $1930 \mathrm{~s}$, the first solitary bryozoan, Monobryozoon ambulans Remane, 1936, was found living in rather shallow sandy sediments (Remane 1936, 1938). Since then, two additional species of this genus were described (Ott 1972, d'Hondt and Hayward 1981, see also Ott and Schwaha in press). Besides those of the genus Monobryozoon, species of solitary or semi-solitary bryozoans have been described in three other genera, Aethozoon Hayward, 1978; Franzenella d'Hondt, 1983; and Nolella Gosse, 1855 (see d'Hondt 1983, Reverter-Gil et al. 2016). All of these belong to the uncalcified Ctenostomata and live on muddy soft bottoms and mostly in the deep sea. The species Aethozoon pellucidum Hayward, 1978 has the broadest documented vertical range, spanning from the deep sea (> $3500 \mathrm{~m}$ ) to about $150 \mathrm{~m}$ water depth (Hayward 1978; Hayward and Erseus 1980).

In general, identification of solitary bryozoans at the genus and also species level is difficult. Monobryozoon can be considered an exception as it is more easily identified owing to the rather globular appearance of the zooids whose total length rarely exceeds two or three times their width. In contrast, the other solitary bryozoan genera show very elongated zooids with the total body length being up to 10 times their width (Ott and Schwaha in press). The solitary elongated forms have elongated cystid appendages, and thin, sometimes motile, body wall outgrowths that face the substrate. The number of these cystid appendages and outgrowths varies among species and are an important diagnostic characteristic. When a cellular pore-cell complex separates the cystid appendage from the remaining zooid, they represent true kenozooids, i.e., stolon-like polymorphic zooids devoid of any feeding structures (Jebram 1973, 1986).

Recently, several solitary, uncalcified bryozoan individuals were found in the eastern Mediterranean Sea (Bernhard et al. 2015) at the upper edge of the halocline of Urania Basin, which is a deep hypersaline anoxic brine (DHAB) lake occurring at about $3.5 \mathrm{~km}$ water depth (Bernhard et al. 2015). To our knowledge, this population represents the first record of deepsea ctenostome Bryozoa from the entire Mare nostrum. Because the bryozoan was quite abundant in one pushcore, it might have been expected to have been found in additional pushcores. However, examination of seven more pushcores from the Urania Basin did not reveal any additional specimens. Furthermore, no bryozoans were observed in any of the 23 pushcore samples examined from two additional DHABs: Discovery $(n=13)$ and L'Atalante $(n=10)$ (Bernhard et al. 2015). It should be noted, however, that dedicated searches solely for this bryozoan were not extensive.
Morphological characteristics suggest that the specimens of this bryozoan belong to a new genus and species for which we provide below a description and formal systematization. A review and perspective of solitary ctenostomes, particularly the family Aethozoidae, is also given.

\section{Material and methods}

\section{Sampling}

Sampling protocol was described in detail by Bernhard et al. (2014), and only a short outline is given here. Sediment samples were collected at the edge of the deep hypersaline anoxic basin Urania Basin ( $35^{\circ} 13.78^{\prime} \mathrm{N} ; 21^{\circ} 28.94^{\prime} \mathrm{E}$ ) using a remotely operated vehicle (ROV) on RV Atlantis cruise AT18-14. For this study, all samples were collected with pushcores. By positioning the ROV on the bottom along the edge of the halocline, it was possible for the robotic arms to reach down into the halocline to collect sediment cores from the transition and into the brine (Bernhard et al. 2015). After selected pushcores were emplaced into the seafloor in desired locations, they were injected with the viability indicator CellTracker Green CMFDA $(\sim 1 \mu \mathrm{M}$ final concentration; Thermo Fisher Scientific). These cores were allowed to incubate in situ for at least $20 \mathrm{~h}$, after which they were collected by the ROV and brought aboard the surface support vessel RV Atlantis. Within about $5 \mathrm{~min}$, pushcores were taken into the ship's environmental room, which was set at $9.5( \pm$ $\left.0.5{ }^{\circ} \mathrm{C}\right), \sim 4{ }^{\circ} \mathrm{C}$ lower than in situ temperature $\left(\sim 14{ }^{\circ} \mathrm{C}\right)$. The cooler temperature was to expedite cooling of the samples, which were subject to warming on ascent and ROV recovery.

As soon as possible, the surface $1 \mathrm{~cm}$ of each sediment core designated for faunal analysis was removed from the core and placed in an HDPE bottle, to which a solution of 3\% glutaraldehyde in $0.1 \mathrm{M}$ cacodylic acid sodium salt was introduced. The sediment sample was gently agitated to fully preserve contents. After preservation, samples were maintained at $\sim 5^{\circ} \mathrm{C}$ until further processing at WHOI. Additional site, sampling, and collection details are provided in Bernhard et al. $(2014,2015)$ and Edgcomb et al. (2016). Metazoans were isolated from the $>$ 63 or $>90 \mu \mathrm{m}$ fraction of preserved sediments after brief sieving with buffered seawater. Isolated specimens were embedded in resin or examined with light microscopy as described below.

\section{Morphological analysis}

A preliminary survey was performed on Cell-Tracker Green CMFDA labeled, glutaraldehyde-fixed, glycerolmounted specimens using a Nikon eclipse 90i microscope (see Figures 6 and 13 in Bernhard et al. 2015). However, the descriptions reported herein are based on specimens that were analyzed and documented with a Nikon SMZ25 stereomicroscope equipped with a DsRi2 microscope 
camera (Nikon, Tokyo, Japan). In addition, some specimens were embedded in Epon-Araldite (Araldite 502/ Embed 812, Electron Microscopy Sciences, Hatfield, PA, USA) resin or Agar LVR resin (Agar Scientific, Stansted, Essex, UK) followed by serial semi-thin sectioning. Ribbons of serial sections of $1 \mu \mathrm{m}$ thickness were obtained using a HistoJumbo diamond knife (Diatome Ltd., Nidau, Switzerland) on a Leica UC6 ultramicrotome (Leica Microsystems, Wetzlar, Germany) as described by Ruthensteiner (2008). Sections were stained with $0.1 \%$ toluidine blue for several seconds at $60{ }^{\circ} \mathrm{C}$. Images of the sections were taken with a Nikon NiU compound microscope equipped with a DsRi2 microscope camera. Image series were converted to gray-scale before being imported into the 3D-reconstruction software Amira 6.3 (FEI, Oregon, USA). Image stacks were aligned with the AlignSlices tool of Amira, followed by semi-automatic and manual segmentation of specific structures and polypide organ systems. Polygonal surfaces of the segmented structures were created, refined, smoothed, and imaged with the snapshot function of Amira; see Ruthensteiner (2008) for details.

\section{Systematics and axis orientation}

Presently, ctenostome bryozoan classification is dynamic. For the purpose of this paper, we follow the classification and systematics of Bock and Gordon (2013), in general, and of Reverter-Gil (2017) for the assignment of the family Aethozoidae to the superfamily Arachnidioidea.

In most ctenostomes, and in fact most bryozoans, the proximo-distal axis defines the growing edge as distal and origin as proximal (Hayward 1985). Since all nonphylactolaemates have anal budding direction, the side of the anal gut shank is defined as distal and the oral as proximal. In accordance with other gymnolaemates, the side of the orifice is determined as frontal and the opposite as basal (Cheetham and Cook 1983).

\section{Results}

\section{Taxonomic treatment}

Class Gymnolemata Allman, 1856

Order Ctenostomata Busk, 1852

Superfamily Arachnidioidea Hincks, 1880

Family Aethozoidae d'Hondt, 1983 (sensu Reverter-Gil et al. 2016)

Genus Aethozooides g. nov.

Diagnosis: Solitary or almost solitary colonies comprising long slender zooids, up to two cystid appendages present on the basal side of zooid, sometimes also on more frontal locations, especially in the mid-region of the elongated fronto-basal axis (i.e., mid-peristomial), terminal frontal appendages at apertural/orificial area rare. Appendages sometimes true kenozooids separated by a cellular pore plate, basal appendage on the distal side with cellular pore plate, i.e., kenozooidal, basal appendage on the proximal side without pore plate. Mid-peristomial appendages kenozooidal. Buds produced at terminal ends of basal cystid appendages or probably from entire midperistomial appendages. Appendages or kenozooids lacking any muscular components. Appendages non-curling. Terminal frontal appendages rare. Pleated collar at vestibular wall present, but short, not exceeding the length of the vestibular wall. Four parieto-vaginal bands from tentacle sheath to distal body wall (in retracted condition); four parieto-vestibular muscles. Size (length) ranges from 1 to $3 \mathrm{~mm}$. Ten tentacles present; retractor muscles insert at the entire oral side of the zooid from the lophophoral base to caecum, parietal muscles a series of transverse bundles in the basal third of the zooid, funiculus probably slender tube from caecum to lateral, anal body wall.

Etymology: The new genus name Aethozooides (masculine gender) is a combination of the known genus name Aethozoon and the Greek suffix oides (ides, oides = descendent of), alluding to the resemblance of the two.

\section{Aethozooides uraniae sp. nov.}

Material examined:

Holotype NHMUK 2018.8.15.1 (Fig. 1), Paratypes: NHMUK 2018.8.15.2-8 (Fig. 2).

Etymology: uraniae refers to the location where the species was first found (see Bernhard et al. 2015).

Type locality: Specimens were collected at $3467.5 \mathrm{~m}$ depth from deep hypersaline, anoxic basin Urania of the Eastern Mediterranean Sea (35 13.783342N; 21 28.941101E). More specifically, animals derive from a pushcore collected by the remotely operated vehicle Jason, from the transition of the normoxic, normal saline sediments to the upper halocline (Bernhard et al. 2015). An image of the site appears in Figure 1c of Bernhard et al. (2015).

Diagnosis: Same as the genus.

Description: Zooids range from 1 to $3 \mathrm{~mm}$ in length and are $\sim 150-250 \mu \mathrm{m}$ wide. The basal appendages range generally in number from one to two (Figs. 3 and 4). The proximally situated basal cystid appendage is in general wider and has no separation from the original zooid via a pore plate, whereas distally situated basal appendages are thinner and are separated via a cellular complex (Fig. 5b). The cellular compartments of the pore complex are located in the mother zooid in the kenozooidal basal cystid appendage (Fig. 6b) but are located within the appendage in the newly formed bud in the kenozooidal mid-peristomial cystid appendage (Fig. 6a). 
Fig. 1 Holotype of Aethozooides uraniae sp. nov. (NHMUK 2018.8.15.1). bca basal cystid appendage, $\mathrm{o}$ orifice, $\mathrm{p}$ polypide

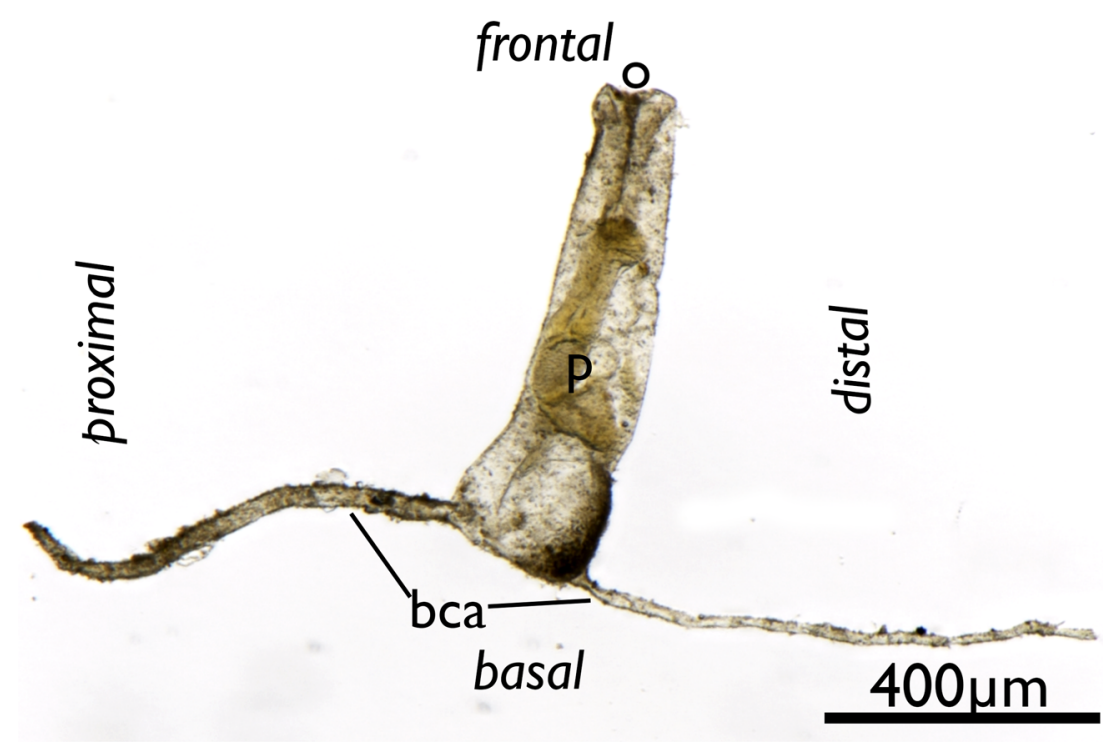

Basal cystid appendages often are very thin and range normally from 10 to $25 \mu \mathrm{m}$ in diameter. One specimen had very large appendages of $\sim 30 \mu \mathrm{m}$ diameter. Appendage length varies extensively from about $300 \mu \mathrm{m}$ to $1 \mathrm{~mm}$. No musculature is present in these appendages, and no distinct association of contact with any substrate particles was observed. Instead, the appendages appear rather flaccid, not capable of any proper mechanical support.

Kenozooidal mid-peristomial appendages range from 0 to 3 in number. They are always shorter than basal cystid appendages and commonly slightly thicker than basal ones, but this might indicate that they are buds or that they may develop into buds. In one specimen, a single kenozooidal mid-peristomial cystid appendage that contained a bud-like structure (Figs. 3 and $4 a-c$ ) was observed.

The frontal aperture or orifice enters into the vestibulum, which represents the terminal invaginated body wall (Figs. 5 and 7). Sometimes, it is distinctly tan to brown in color, and in general, it is rather short (Fig. 4a, b). The lining, known as the vestibular wall, continues with a diaphragmatic sphincter that separates the frontal vestibulum from a more basally located cavity called the atrium. The atrium is only distinguishable in retracted zooids as it contains the retracted tentacle crown or lophophore (Fig. 3). The epithelium of the vestibular wall continues past the diaphragmatic sphincter into the tentacle sheath, which is an introvertable part surrounding the retracted lophophore. Consequently, when animals protrude the tentacle sheath, the total length of zooids is increased by about $750-1000 \mu \mathrm{m}$.

The tentacle sheath encloses the lophophore which in all analyzed specimens had 10 tentacles. Distinct intertentacular pits are located at the lophophoral base (Figs. 7 and 8c). The digestive tract continues from the mouth opening at the lophophoral base into the foregut (pharynx and esophagus) and continues into the cardia and stomach or caecum. At the transition of foregut into the cardia lies the cardiac valve. The caecum is very small and continues with a short intestine and anus into the tentacle sheath (Figs. 3, 5e, and 7). At the lophophoral base, adjacent to the pharyngeal epithelium lies the cerebral ganglion (Fig. 8b).

In the apertural area, distinct parieto-vestibular and parietovaginal bands can be easily distinguished (cf. Schwaha et al. 2011) These are arranged in a fourfold symmetry in A. uraniae and are easily differentiable (Figs. 3 and 7).

The retractor muscles in A. uraniae originate from a single site of the lateral, proximal cystid wall. These insert at several locations on the polypide: at the lophophoral base, the foregut, and parts of the caecum (Fig. 7).

In one specimen, an intertentacular organ (ITO) was observed at the lophophoral base (Fig. 5a). Gonads were rare in the analyzed specimens of $A$. uraniae. Clusters of cells resembling undifferentiated spermatogonia located at the lateral body wall were detected in a few specimens (Fig. 5a, d). Small oocytes were detected close to the proximal part of the caecum (Fig. 6d). In addition, one specimen had oocytes in the frontal area attached to the lateral body (Fig. 5c).

Fig. 2 Zooids of Aethozooides uraniae sp. nov. a Slightly bent specimen with two basal appendages; $\mathbf{b}$ Short specimen with cystid appendages on the terminal frontal, mid-peristomial, and basal side of the zooid. Note that the polypide appears already degenerated in this case; $\mathbf{c}$ Paratype (NHMUK 2018.8.15.8) with two basal cystid appendages and two midperistomial ones; $\mathbf{d}$ Similar zooid as in $\mathrm{C}$ with two basal and midperistomial cystid appendages. bca basal cystid appendage, fca terminal frontal cystid appendage, mca kenozooidal, mid-peristomial cystid appendage, o orifice, $\mathrm{p}$ polypide 
a

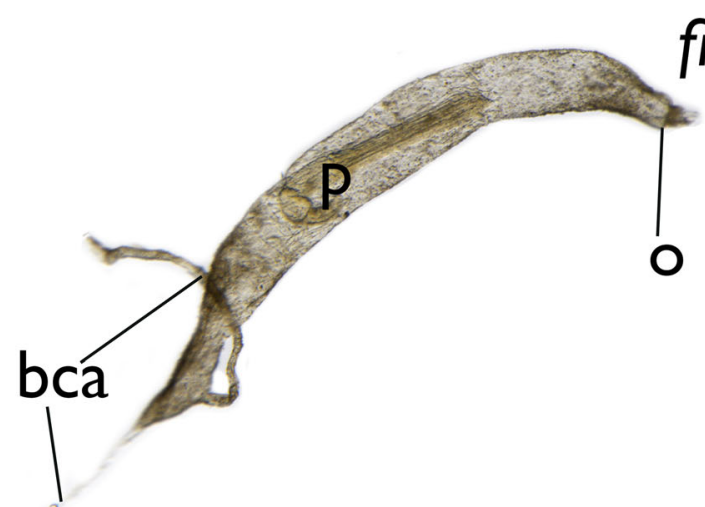

frontal

$500 \mu \mathrm{m}$

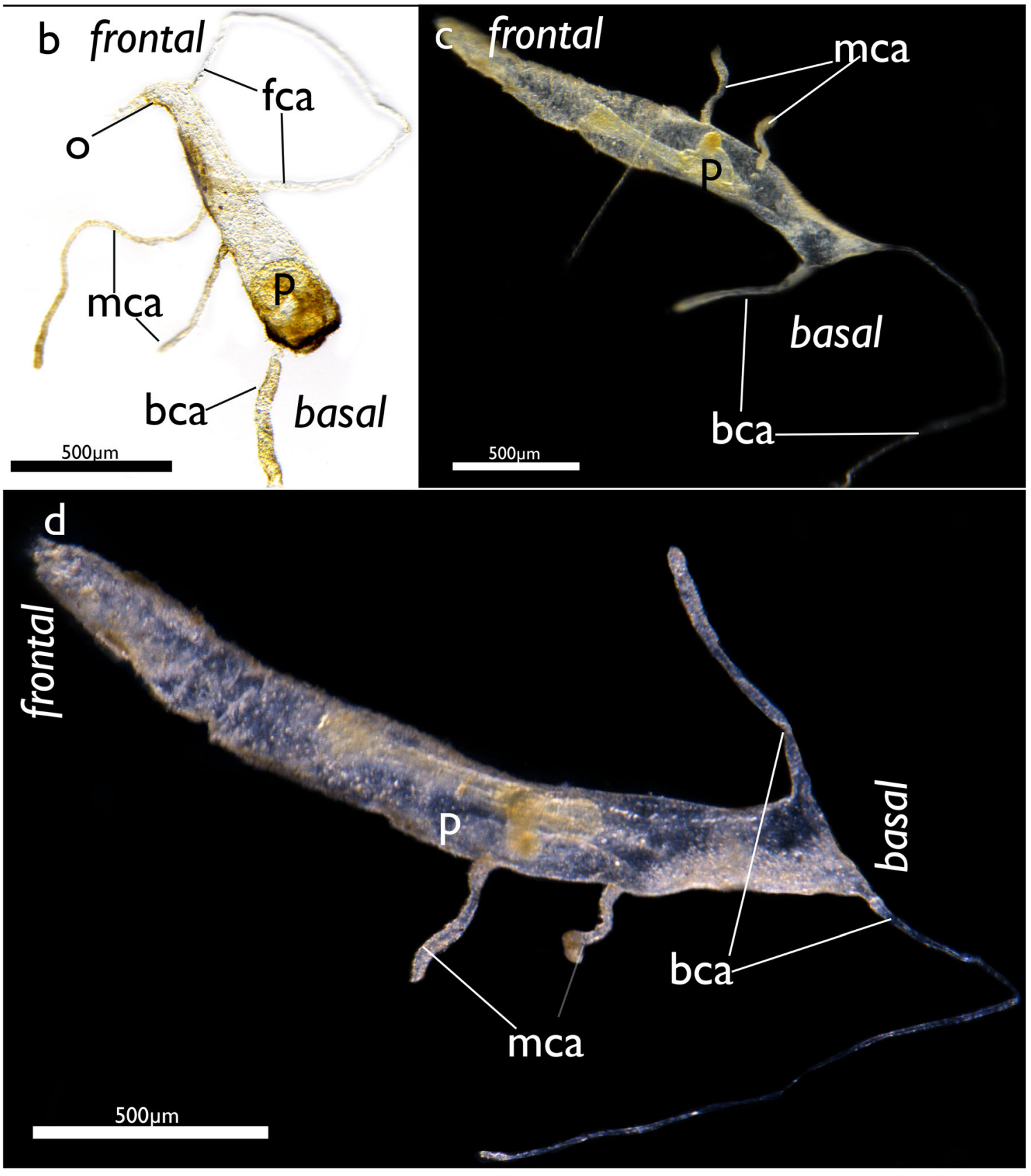




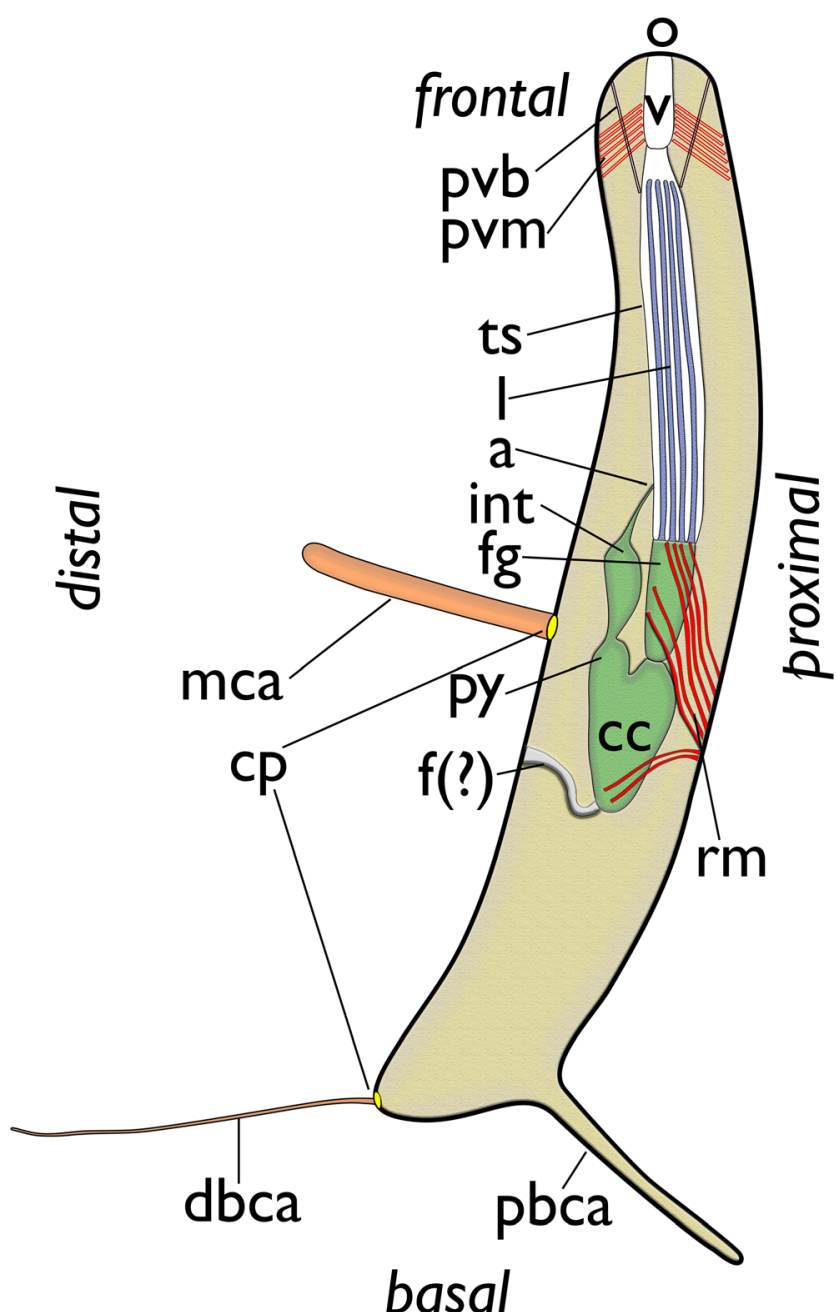

Fig. 3 Schematic drawing of a zooid of Aethozooides uraniae sp. nov. General morphology of $A$. uraniae sp. nov. showing a single midperistomial cystid appendage and two basal cystid appendages. Note that the presence and size of these appendages shows considerable variation (see text for details). a anus, $\mathrm{f}($ ?) funiculus, cc caecum, cp communication pores, dbca (kenozooidal) distal basal cystid appendage, fg foregut, int intestine, 1 lophophore, mca (kenozooidal) mid-peristomial cystid appendage, o orifice pbca proximal basal cystid appendage, py pylorus, pvb parieto-vaginal bands, pvm parieto-vestibular muscles, $\mathrm{rm}$. retractor muscle, ts tentacle sheath, $v$ vestibulum

\section{Discussion}

\section{Remarks on morphological characters}

\section{Autozooidal characters}

Cystid appendages are typical and diagnostic for the ctenostome superfamily Arachnidioidea (Jebram 1973, 1986). Pore complexes separating zooids in gymnolaemates have three distinct cell types: cincture, limiting, and special cells (Bobin 1977). These are distributed equally over both sides of the pore complex, with the exception of the special cells, which are dumbbell shaped and stretch through the pores through the cuticle. These cellular plugs show a polarity in the complex with the nuclei being restricted to the proximal part of the connection, whereas the distal part represents a mere cytoplasmatic extension (Banta 1969, Bobin 1977). A. uraniae seems to be unique in that the entire pore complex is asymmetrically distributed between autozooid and kenozooid.

The proximal basal cystid appendage of Aethozooides uraniae (and Aethozoon) is probably homologous to the proximal thin and elongated portion or cauda of other arachnidioidean ctenostomes (cf. Todd 2000). However, since the condition and homology of these in other aethozoids is not clarified, we consider the term cystid appendage more appropriate until new studies on other genera appear.

The lophophore and digestive tract is similar to that described in other species (Mukai et al. 1997). Intertentacular pits as encountered in A. uraniae are common for all Gymnolaemata (see Weber et al. 2014, Schwaha and Wanninger 2018). The retractor muscle of A. uraniae inserts at several areas of the polypide, whereas it inserts only at the lophophoral base in most analyzed Gymnolaemata (Mukai et al. 1997).

In the apertural area, parieto-vaginal bands (= duplicature bands) are present in A. uraniae. So far, these have not been described for any solitary bryozoans, but they are easily overlooked, being indistinguishable in simple whole mounts and requiring observation of sections for proper identification. In the solitary Franzenella limicola (Franzen, 1960) some fibers reminiscent of these bands were designated simply as "muscles," which indicates that these structures are probably present. Previous assumptions that species with large peristomes might lack any parieto-vaginal bands (Schwaha et al. 2011) are thus not confirmed (see also Schwaha \& Wanninger 2018).

\section{Reproductive characters}

In A. uraniae, asexually produced buds are either produced from mid-peristomially positioned kenozooidal appendages or at the terminal end of the proximal basal cystid appendage. This situation coincides closely with the situation of Aethozoon pellucidum, whereas only the terminal buds on basal, and probably kenozooidal, appendages are described for Franzenella limicola. Distinct differentiation of the polypide bud in the kenozooidal mid-peristomial appendages was observed only once in A. uraniae. Since these appendages are not found in all species, we conclude that these probably are all budding zooids that separate from the adult. The rare occurrence of buds or bud-like structures indicates that budding either is not very frequent or a very fast process. The encountered abundance of single zooids (Bernhard et al. 2015) suggests the latter. 


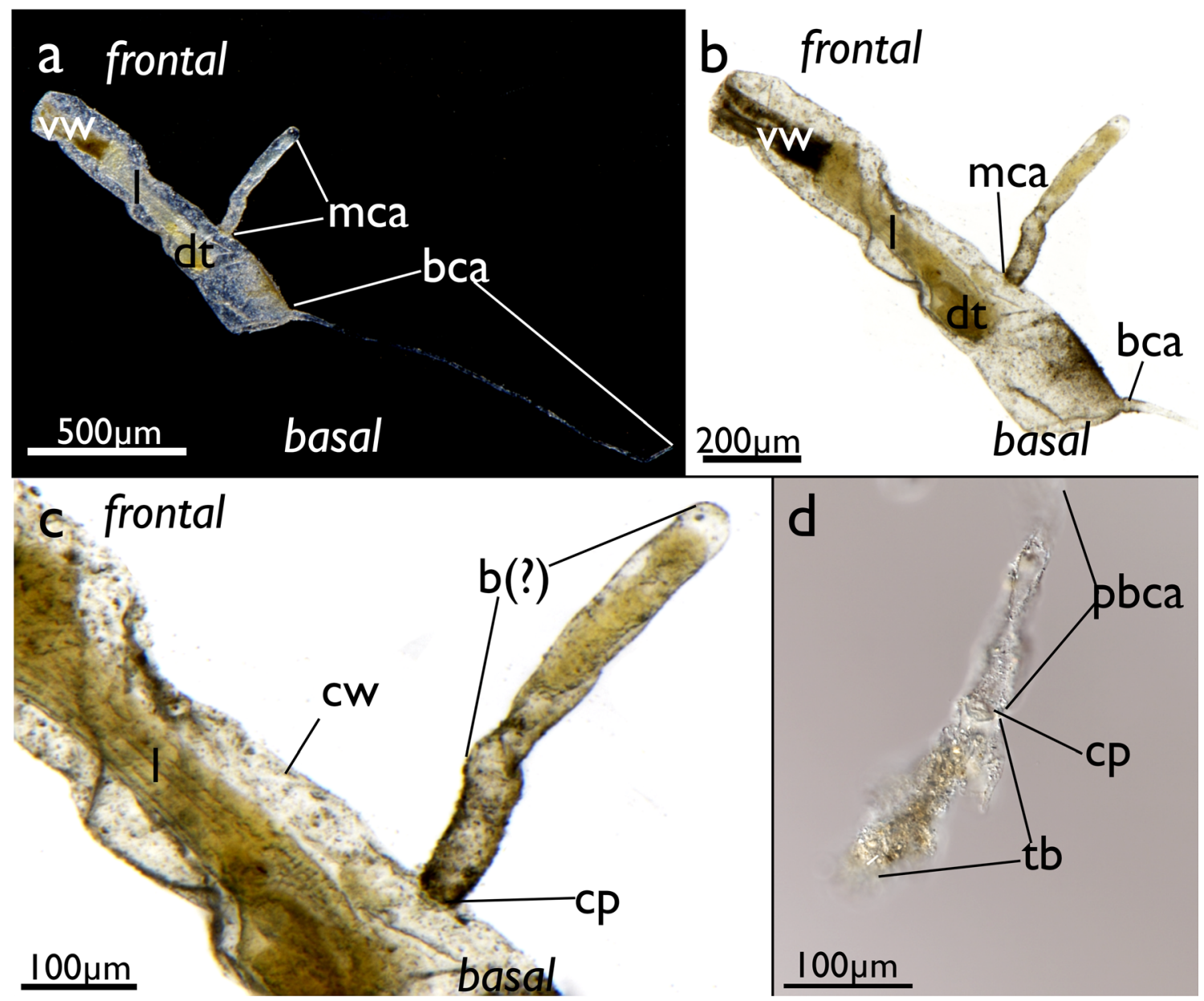

Fig. 4 Buds in Aethozooides uraniae sp. nov. a-c Same specimen (Paratype NHMUK 2018.8.15.3) showing a probable bud in the kenozooidal mid-peristomial cystid appendage. a General overview showing the elongated basal cystid appendage and the mid-peristomial one; $\mathbf{b}$ Detail of the main body of the specimen; $\mathbf{c}$ Detail of the bud with differentiating tissues in the mid-peristomial cystid appendage; $\mathbf{d}$ Detail

Few observations regarding sexual reproduction of A. uraniae were present in the analyzed specimens. Small oocytes close to the proximal part of the caecum are also found in Aethozoon pellucidum (Hayward and Erseus 1980) and Franzenella limicola (Franzen 1960). A distal occurrence of oocytes as observed in A. uraniae has been found in F. limicola, but not in A. pellucidum. Distinct spermatocytes were detected only in F. limicola. These develop from testes clustered on the body wall close to the stomach caecum of the zooid (Franzen 1960). In both, A. uraniae and A. pellucidum, only undifferentiated cell clusters associated with the body wall, which resemble spermatogonia, were encountered, but distinct spermatocytes were not observed.

Aethozooides uraniae possess an intertentacular organ, which is also present in Franzenella limicola. In Aethozoon pellucidum no intertentacular organ has been detected so far. Intertentacular organs are associated with a non-brooding reproductive pattern, where many oligolecithal zygotes are of a terminal bud separated via a communication pore complex from the proximal basal cystid appendage. Paratype NHMUK 2018.8.15.7. b bud, bca basal cystid appendage, cp communication pore, $\mathrm{cw}$ cystid wall, $\mathrm{dt}$ digestive tract, 1 lophophore, mca kenozooidal mid-peristomial cystid appendage, pbca proximal basal cystid appendage, tb terminal bud on proximal basal cystid appendage, vw vestibular wall produced that are shed via the intertentacular organ (ITO) into surrounding water to produce planktotrophic cyphonautes larvae (Ostrovsky and Porter 2011). Given the unusual habitat, planktotrophic larvae can confer an advantage as they are long-lived and can settle in areas far away from the parent individual allowing wider dispersal (Ostrovsky 2013). Reproduction in the solitary Monobryozoontidae is not well known. Gonads have been observed, and particularly, the large eggs in Monobryozoon bulbosum (Ott, 1972) indicate that some kind of brooding and lecithotrophy is more likely.

\section{Taxonomic remarks}

\section{Comparison to Aethozoon, Hayward 1978}

Free-living, (semi-)solitary forms similar to Aethozooides uraniae are found in the genera Aethozoon and Franzenella. Currently, Aethozoon includes a single species and 


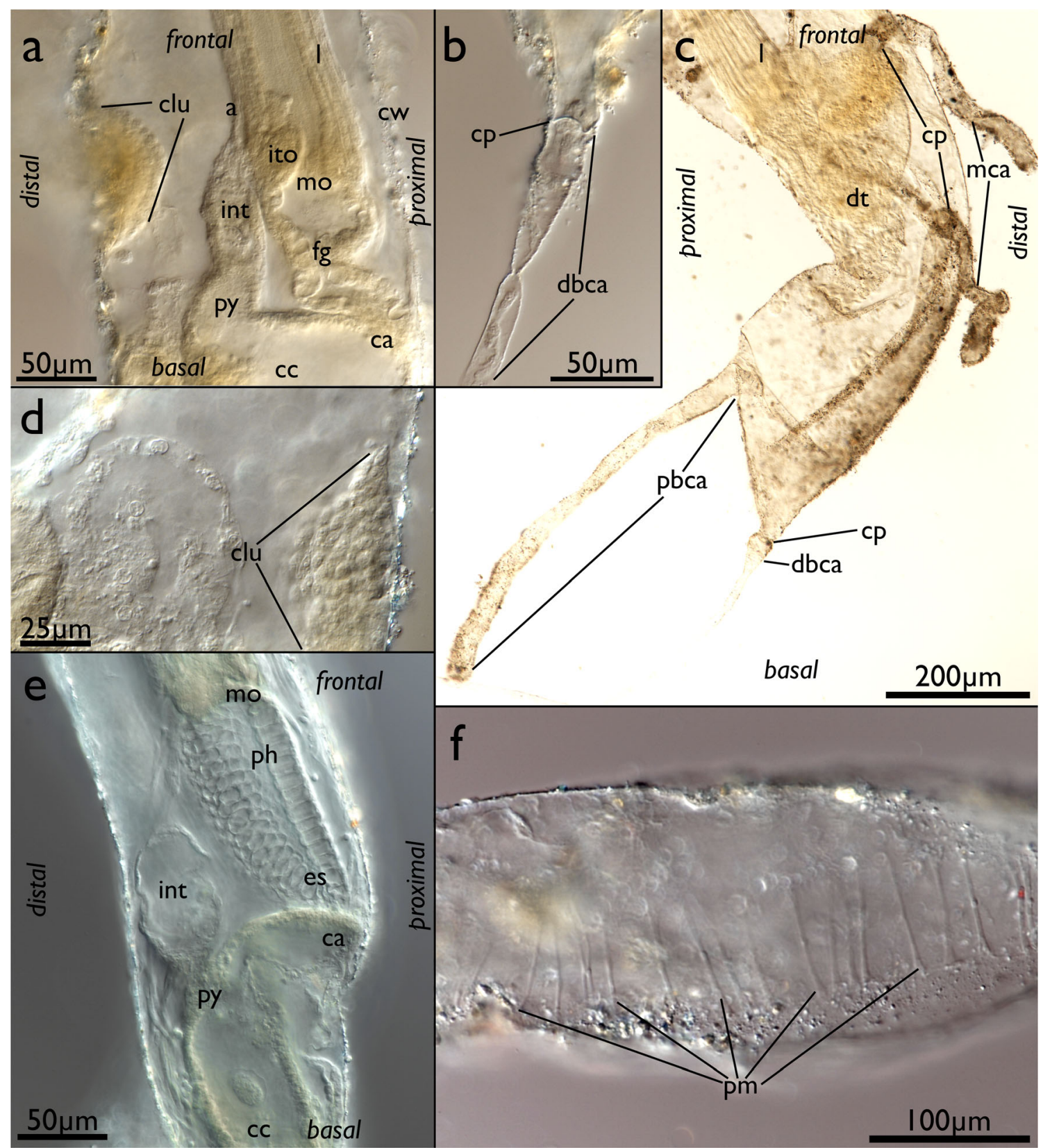

Fig. 5 Details of whole-mounts of Aethozooides uraniae sp. nov. a Cell cluster in association with a kenozooidal mid-peristomial cystid appendage. Note also the vase-shaped intertentacular organ. Paratype NHMUK 2018.8.15.6; b Kenozooidal basal appendage with communication pore (cystidial, cuticular separation from original zooid). Paratype NHMUK 2018.8.15.6; $\mathbf{c}$ Basal part of a zooid showing a basal cystid appendage on the proximal side with wide opening, lacking any separation from the original zooids vs. the separated much thinner kenozooidal cystid appendage on the distal side of the zooid. Paratype NHMUK 2018.8.15.8; d Cell cluster on the lateral body wall, perhaps representing a testis; e Detail showing the vacuolated cells of the

Franzenella three species (Table 1). The new species from the Mediterranean Sea resembles most closely Aethozoon pellucidum Hayward, 1978. However, the two species can be separated based on the following characters: (1) In Aethozoon pellucidum, only a single basal appendage similar foregut (pharynx and esophagus) and the remaining parts of the digestive tract. Paratype NHMUK 2018.8.15.7; f Laterally positioned parietal muscles of a zooid enabling polypide protrusion typical of all Gymnolaemata. Paratype NHMUK 2018.8.15.7. a anus, ca cardia, cc caecum, clu cluster of cells, cp communication pore, cw cystid wall, dbca kenzooidal distal basal cystid appendage, dt digestive tract, es esophagus, fg foregut, int intestine, ito intertentacular organ, 1 lophophore, mca kenozooidal mid-peristomial cystid appendage, mo mouth opening, pbca proximal basal cystid appendage, ph pharynx, pm parietal muscles, py pylorus

to the non-kenozooidal cystid appendage of Aethozooides is present, whereas the kenozooidal one on the distal side is missing; (2) zooids of Aethozoon pellucidum are much bigger (6-10 mm vs. $3 \mathrm{~mm}$ ); (3) the lophophore of Aethozooides uraniae carries 10 tentacles vs. that of Aethozoon ( $\sim 25)$; and 
Fig. 6 Histological details of Aethozooides uraniae sp. nov. a Detail of the pore complex of a kenozooidal mid-peristomial cystid appendage with the main cellular components in the appendage; $\mathbf{b}$ Detail of the pore complex of a kenozooidal basal cystid appendage with the main cellular components in the mother (budding) zooid; c Oocytes in the distal area, close to the orifice; $\mathbf{d}$ An oocyte close to the proximally located caecum; e Detail of the short collar. c collar, cc caecum, cp communication pore, $\mathrm{cw}$ cystid wall, dbca kenozooidal distal basal cystid appendage, 1 lophophore, mca kenozooidal mid-peristomial cystid appendage, mz mother zooid, ooc oocyte

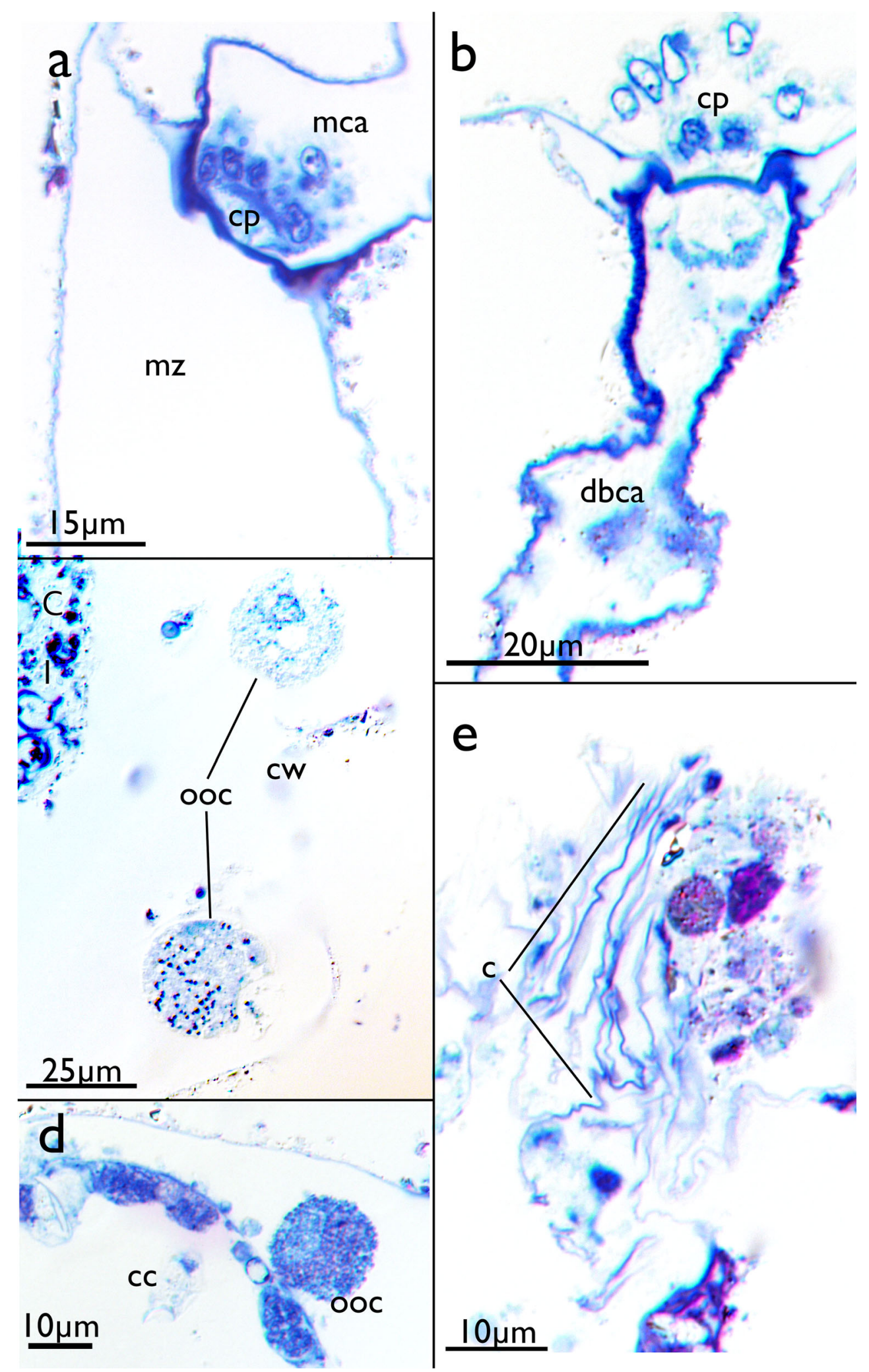

(4) retractor muscles in Aethozoon pellucidum insert only at the pharynx (Hayward \& Erseus 1980), whereas they insert over the whole range of the digestive tract in Aethozooides uraniae (Fig. 7). With regard to this last trait, it might be possible that more basally located retractor fibers had been overlooked in A. pellucidum. A future study should better clarify this. (5) A large portion of the zooidal tube was accounted for as introvertable peristomial 
Fig. 7 3D reconstruction of a zooid of Aethozooides uraniae sp. nov. showing the main parts of the polypide. a Lateral view with the proximal side on the left and the distal on the right; $\mathbf{b}$ View from the distal side on the polypide showing the location of the cerebral ganglion between the gut shanks. a anus, ca cardia, cc caecum, cg cerebral ganglion, es esophagus, f funiculus, int intestine, 1 lophophore, ph pharynx, pvb parieto-vaginal bands, pvm parieto-vestibular muscles, py pylorus, rm retractor muscles
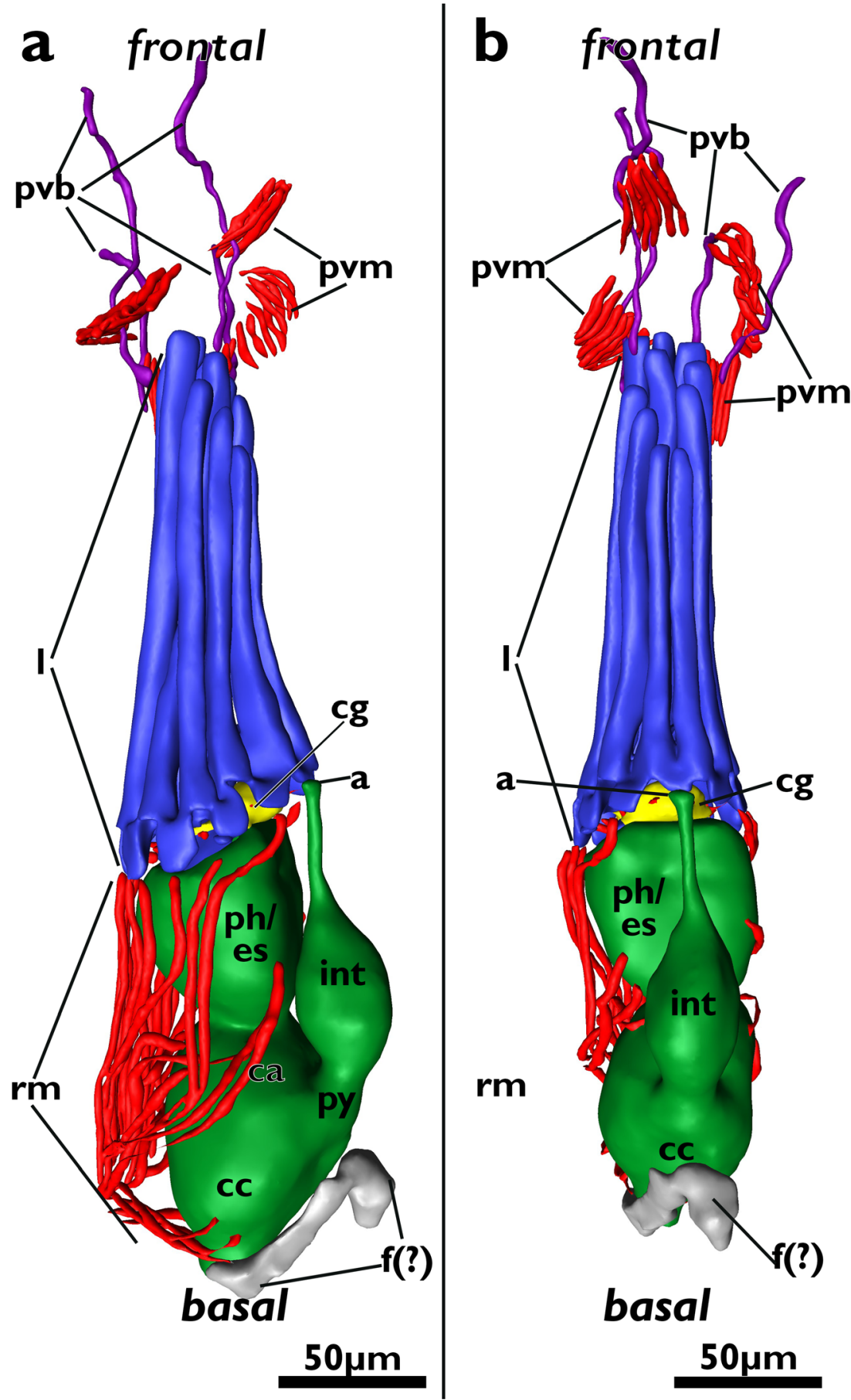

tube in Aethozoon (Hayward 1978, Hayward and Erseus 1980). It appears to be slightly more slender than the more basal part of the zooid, but effectively, it remains difficult to define a peristomial tube in this context. From a comparative morphological view and taking into account a closer relationship to nolellid ctenostomes (Hayward 1978), the entire zooidal tube might be considered to represent the elongated peristomial tube. Under this interpretation, only the most frontal portion of the peristomial tube can be regarded as introvertable in Aethozoon pellucidum.
Regardless of the interpretation chosen, in Aethozooides, a distinct introverted area of this tube could not be recognized nor could any strong evidence of thinning in the frontal region. The presence of parieto-vaginal bands, which remain unknown in Aethozoon, also would prevent a large area being introverted from the peristomial tube (Fig. 7).

Buds in Aethozoon pellucidum and Aethozooides uraniae appear similar. In both species, the proximal basal cystid appendage can form a bud at its terminal end (compare Fig. 1D 


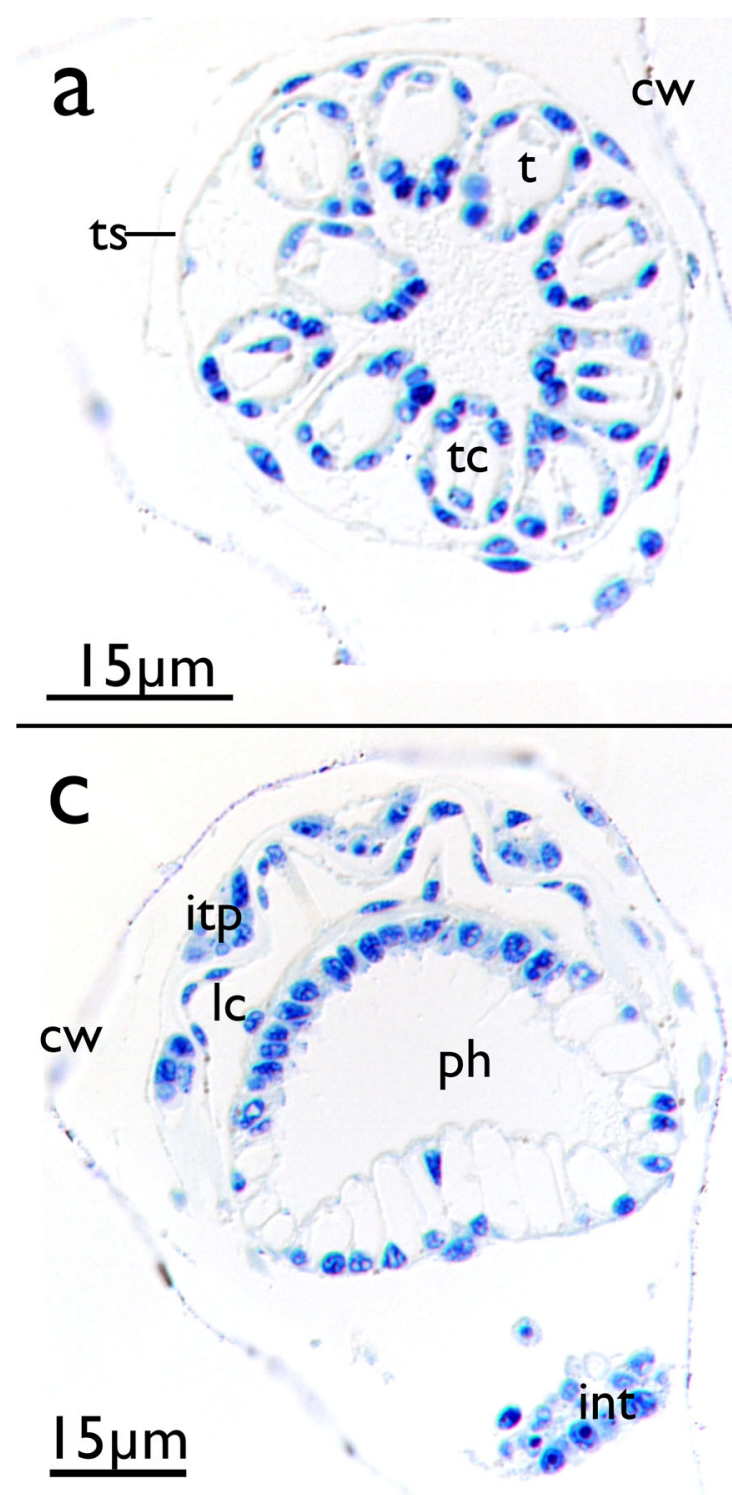

Fig. 8 Histological cross section of a zooid of Aethozooides uraniae sp. nov. a Cross section of the retracted tentacle crown showing 10 tentacles; b Cross section of the lophophoral base showing the cerebral ganglion; c Cross section of the foregut showing the round lumen of the pharynx; $\mathbf{d}$ Cross section of the proximal caecum showing a thin, hollow tissue cord

in Hayward 1978 and our Fig. 4d). Mid-peristomial kenozooids seem to develop into buds in both genera. In Aethozooides, only a single observation showed the kenozooid to form a distinct polypide bud (Fig. 4a-c). In Aethozoon, buds from the Mid-peristomial kenozooids developed at the distal end of these appendages (Hayward 1978), whereas in Aethozooides uraniae, the entire appendage is a bud without proximal elongation.

Aethozooides uraniae shares some morphological similarity (e.g., body proportions) with species of the genus Franzenella, in particular with the type species $F$. limicola (Franzen, 1960). However, the two taxa can easily be discerned based on (1) the type of predominantly kenozooidal

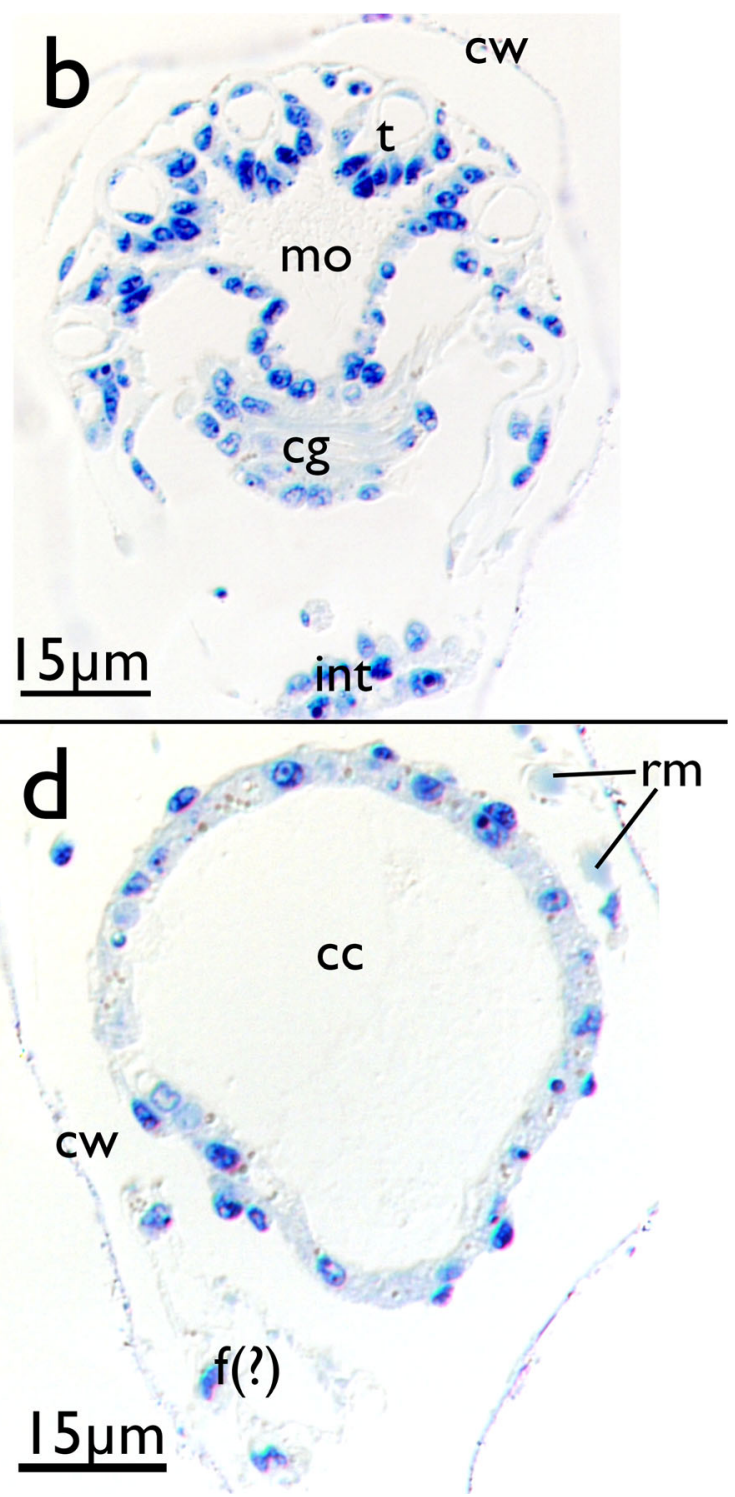

interpreted as funiculus. cc caecum, cg cerebral ganglion, cw cystid wall, $\mathrm{f}$ funiculus, int intestine, itp intertentacular pits, lc lophophoral coelom, mo mouth opening, ph pharynx, rm retractor muscles, $t$ tentacle, tc tentacle coelom, ts tentacle sheath

cystid appendages and higher number (typically two to three but up to seven in Franzenella vs. a maximum of two in Aethozooides), (2) length of appendages $(2.5 \mathrm{~mm}$ in Franzenella vs. 0.3-1 mm in Aethozooides), (3) kenozooids contain muscles that are missing in any appendage of Aethozooides, (4) buds are reported being formed only terminally on the appendages in Franzenella, and (5) the funicular cord extends from the caecum proximally in Franzenella, but laterally in Aethozooides (data missing for Aethozoon). The distinguishing features are summarized in Table 2.

With regard to the other two species currently assigned to the genus Franzenella (i.e., F. monniotae (d'Hondt 1976) and F. radicans (d'Hondt and Hayward, 1981)), it 
Table 1 Solitary bryozoans of revised family Aethozoidae including original classification, past changes, and proposed changes. Abbreviations: bcabasal cystid appendage, $\mathrm{k}$ —-kenozooidal, mca — mid-peristomial cystid appendage, $\mathrm{n}-\mathrm{k}$ —non-kenozooidal

\begin{tabular}{|c|c|c|c|c|c|c|}
\hline $\begin{array}{l}\text { Species original } \\
\text { description }\end{array}$ & $\begin{array}{l}\text { First description } \\
\text { reference }\end{array}$ & $\begin{array}{l}\text { Taxonomic } \\
\text { changes }\end{array}$ & $\begin{array}{l}\text { Changes } \\
\text { reference }\end{array}$ & $\begin{array}{l}\text { Proposed } \\
\text { change }\end{array}$ & $\begin{array}{l}\text { Taxonomic } \\
\text { characters }\end{array}$ & $\begin{array}{l}\text { Locality, depth } \\
\text { range }\end{array}$ \\
\hline Monobryozoon limicola & Franzen 1960 & $\begin{array}{l}\text { Genus to } \\
\quad \text { Franzenella }\end{array}$ & d'Hondt 1983 & & bca: $\mathrm{k}$ & $\sim 55 \mathrm{~m}$ depth \\
\hline Nolella radicans & $\begin{array}{l}\text { d'Hondt \& } \\
\quad \text { Hayward } 1981\end{array}$ & Genus to Franzenella & d'Hondt 1983 & n. gen. Solella & $?$ & Deep sea, 5073m* \\
\hline Nolella monniotae & d'Hondt 1976 & Genus to Franzenella & d'Hondt 1983 & n. gen. Solella & $?$ & Deep sea, $4680 \mathrm{~m}^{*}$ \\
\hline Aethozoon pellucidum & Hayward 1978 & & & & bca: n-k mca: k, & $\begin{array}{l}\text { Shallow to deep sea, } \\
\quad 150-3617 \mathrm{~m}\end{array}$ \\
\hline Aethozooides uraniae & this study & & & & $\begin{array}{l}\text { bca: } k+n-k \\
\text { mca: } k\end{array}$ & Deep sea, 3468 m \\
\hline
\end{tabular}

*Type locality only. The species had been found in subsequent surveys of deep sea habitats of similar depth

should be highlighted that their systematization is problematic. Originally placed in the genus Nolella, these species were subsequently moved to the current genus (e.g., Reverter-Gil et al. 2016). However, owing to the scanty descriptions and the absence of many key features found in the nominal species of the genus Franzenella, in our opinion, they should not be included in Franzenella (see below).

In conclusion, the autapomorphic traits of the specimens from the Urania Basin leave no doubts about the fact that they belong to a new species. Moreover, the new species cannot be accommodated in any of the two most closely related genera (e.g., Aethozoon and Franzenella) without grossly extending the respective generic boundaries. This is primarily due to, e.g., the size of zooids, number of appendages, and presence of non-curling appendages. Consequently, we propose the establishment of Aethozooides gen. nov. to allocate this novel species.

\section{Systematic revision of solitary bryozoans}

All solitary bryozoans belong to the ctenostome Gymnolaemata. Prior to this study, the three genera that include solitary species were distributed in three families: Monobryozoon Remane, 1936 (Monobryozoontidae); Aethozoon Hayward, 1978 (Aethozoidae); and Franzenella d'Hondt, 1983 (Arachnidiidae, see below). The general body proportions in zooids of these solitary taxa differ significantly, with, e.g., zooids of Monobryozoontidae being up to three times as long as wide and those of Aethozoidae being 8-10 times longer than wide. In addition, buds of monobryozoontids are bulbous, roundish structures always on the proximal side, while in aethozoids, these buds are variable in their location and form (see above). Based on these distinctions, it is reasonable to hypothesize that solitary forms evolved independently at least twice, once along the evolutionary line of the Monobryozoontidae and once in that of the
Aethozoidae (see also Ott and Schwaha in press). Aethozoidae currently includes solely the genus Aethozoon; however, based on the many, likely homologous, traits shared between Aethozoon and Aethozooides, we infer that the new genus should also be included in this family. Moreover, the solitary status and the body proportion of the zooids that Aethozoon and Aethozooides share with F. limicola suggest that this latter species is also part of the same clade. Consequently, we propose its transfer to the family Aethozoidae. Finally, two species of solitary ctenostome bryozoans originally assigned to the genus Nolella, but currently affiliated to the genus Franzenella (i.e., $F$. monniotae and $F$. radicans), should also be assigned to the Aethozoidae. Because the descriptions of the last two species lack any detailed information on important diagnostic features such as the pore complexes and the internal structures, in our opinion, it is very doubtful to assign them to the genus Franzenella. Additionally, we note that while F. limicola is found in rather shallow water, the other two species occur in deeper water depths (see Table 1). The assignment of $F$. monniotae and $F$. radicans to their original genus Nolella is problematic considering, among other things, the colonial nature of all other congeners. Consequently, to avoid inclusion of solitary and colonial species in one genus, we propose the establishment of a new taxon, Solella gen. nov., and the transfer of $F$. monniotae and $F$. radicans into this new genus. We propose below an emended or new diagnosis for the relevant taxa.

\section{Family Aethozoidae}

Emended diagnosis: Solitary bryozoans 8 to 10 times longer than wide, characterized by thin cystid appendages always on the basal; sometimes on the mid-peristomial and rarely on the terminal frontal side of zooids. Appendages may be kenozooidal. Size commonly several 
millimeters up to $\sim 10 \mathrm{~mm}$. Type genus. Aethozoon Hayward, 1978; other genera: Aethozooides new genus, Franzenella d'Hondt, 1983, Solella new genus.

Genus Franzenella d'Hondt, 1983

Emended diagnosis: More than two basal cystid appendages possible, buds produced on distal tip of basal cystid appendages; basal cystid appendages with muscles and sometimes branched; pore complexes present between original zooid and basal cystid appendages, mid-peristomial cystid appendages possible (kenozooidal nature probable, but not yet observed). Type species: Franzenella limicola (Franzen, 1960)

Genus Solella g. nov.

Etymology: Solella being a combination of 'Solitary' and the genus 'Nolella', the genus to which the species were originally assigned.

Diagnosis: Solitary aethozoids generally with one to six basal appendages, mid-peristomial cystid appendages not present, cystid appendages non-curling and generally short ranging from $0.2-0.4 \mathrm{~mm}$, pore complex traits unknown. Type species: Solella monniotae (d'Hondt, 1976); other species: S. radicans (d'Hondt \& Hayward, 1981).

Acknowledgments The authors thank the captain, crew, and science party of the RV Atlantis and the AT18-14 ROV Jason team, Phil Forte for engineering assistance, and Lydia Dick and Alec Cobban for laboratory assistance. We thank one anonymous reviewer and Jon A. Todd for their valuables comments that helped to improve the manuscript.

Funding information Open access funding provided by University of Vienna. This study was supported by NSF grants OCE-0849578 to VPE and JMB, OCE-1061391 to JMB and VPE, and The Investment in Science Fund at WHOI.

\section{Compliance with ethical standards}

Conflict of interest The authors declare that they have no conflict of interest.

Ethical approval All applicable international, national, and/or institutional guidelines for the care and use of animals were followed by the authors.

Sampling and field studies All necessary permits for sampling and observational field studies have been obtained by the authors from the competent authorities and are mentioned in the acknowledgements, if applicable.

Data availability statement All data generated or analysed during this study are included in this published article

Open Access This article is distributed under the terms of the Creative Commons Attribution 4.0 International License (http:// creativecommons.org/licenses/by/4.0/), which permits unrestricted use, distribution, and reproduction in any medium, provided you give appropriate credit to the original author(s) and the source, provide a link to the Creative Commons license, and indicate if changes were made. 


\section{References}

Allman GJ (1856) A monograph of the fresh-water Polyzoa. Ray Soc Lond 28:1-119

Banta WC (1969) The body wall of cheilostome Bryozoa. II. Interzoidal communication organs. J Morphol 129:149-170

Bernhard JM, Kormas K, Pachiadaki MG, Rocke E, Beaudoin DJ, Morrison C, Visscher PT, Cobban A, Starczak VR, Edgcomb VP (2014) Benthic protists and fungi of Mediterranean deep hypsersaline anoxic basin redoxcline sediments. Front Microbiol 5:605

Bernhard JM et al (2015) Metazoans of redoxcline sediments in Mediterranean deep-sea hypersaline anoxic basins. BMC Biol 13: 105

Bobin G (1977) Interzooecial communications and the funicular system. In: Woollacott RM, Zimmer RL (eds) Biology of bryozoans. Academic Press, New York, pp 307-333

Bock P, Gordon DP (2013) Phylum Bryozoa Ehrenberg, 1831. Zootaxa 3703:67-74

Busk G (1852) An account of the Polyzoa and sertularian zoophytes collected in the voyage of the rattlesnake on the coasts of Australia and Louisiade Archipelago. In: MacGillivray J (ed) Narrative of the voyage of H.M.S. rattlesnake commaned by the late Captain Owen Stanley, during the years 1846-1850. T\&W Boone, London, pp 343-402

Cheetham AH, Cook PL (1983) General features of the class Gymnolaemata. In: Robinson RA (ed) Treatise on invertebrate paleontology. Part G: Bryozoa. pp 138-207

Cook PL (1988) Bryozoa. In: Higgin RP, Theil H (eds) Introduction to the study of Meiofauna. Smithsonian Institution Press, Washington, D. C, pp 438-443

Edgcomb VP, Pachiadaki MG, Mara P, Kormas KA, Leadbetter ER, Bernhard JM (2016) Gene expression profiling of microbial activities and interactions in sediments under haloclines of E. Mediterranean deep hypersaline anoxic basins. ISME J 10:2643-2657

Ernst A, Schäfer P (2006) Palaeozoic vs. post-Palaeozoic Stenolaemata: phylogenetic relationship or morphological convergence? Cour Forschungsinstit Senck 257:49-64

Franzen A (1960) Monobryozoon limicola n.sp., a ctenostomatous bryozoan from the detritus layer on soft sediment. Zoologiska Bidrag från Uppsala 33:135-148

Gosse PH (1855) Notes on some new or little-known animals. Annals and Magazine of Natural History series 2(16):27-36

Hayward PJ (1978) Two species of Ctenostomata (Bryozoa) from the Norwegian Sea. Sarsia 63:159-162

Hayward PJ (1985) In: Kermack DM, Barnes RSK (eds) Ctenostome Bryozoans. E.J. Brill/Dr.W. Backhuys for The Linnean Society of London \& The Estuarine and Brackish-Water Siences Association, London, Leiden, Köln, Kobenhavn 169 p

Hayward PJ, Erseus C (1980) Morphology and distribution of Aethozoon pellucida (Bryozoa Ctenostomata). Sarsia 65:243-248

Hincks T (1880) A history of the British marine Polyzoa. Van Voorst, London

Hirose M (2011) Orientation and righting behavior of the sand-dwelling bryozoan Conescharellina catella. Invertebr Biol 130:282-290
Hondt J-L d' (1976) Bryozoaires cténostomes bathyaux et abyssaux de l'Atlantique Nord. In: Pouyet S (ed) Bryozoa 1974. Université Claude Bernard, Lyon, pp 311-333

Hondt J-L d' (1983) Tabular keys for identification of the recent Ctenostomatous Bryozoa Mémoires de L'Institut Océanographique. Monaco 14:1-134

Hondt J-L d', Hayward PL (1981) Nouvelles recoltes de Bryozoaires Cténostomes bathyaux et abyssaux. Cah Biol Mar 22:267-283

Jebram D (1973) Stolonen-Entwicklung und Systematik bei den Bryozoa Ctenostomata. Z Zool Syst Evol 11:1-48

Jebram D (1986) The ontogenetical and supposed phylogenetical fate of the parietal muscles in the Ctenostomata (Bryozoa). Z Zool Syst Evol 24:58-82

Mukai H, Terakado K, Reed CG (1997) Bryozoa. In: Harrison FW, Woollacott RM (eds) Microscopic anatomy of invertebrates, vol 13. Wiley-Liss, New York, Chichester, pp 45-206

Ostrovsky AN (2013) Evolution of sexual reproduction in marine invertebrates: example of gymnolaemate bryozoans. Springer, Dordrecht, Heidelberg, New York, London

Ostrovsky AN, Porter JS (2011) Pattern of occurrence of supraneural coelomopores and intertentacular organs in Gymnolaemata (Bryozoa) and its evolutionary implications. Zoomorphology 130: $1-15$

Ott JA (1972) Monobryozoon bulbosum n. sp., a new solitary interstitial bryozoan from the West Atlantic coast. Cah Biol Mar 13:421-428

Ott JA, Schwaha T (in press) Chapter Bryozoa. In: A. Schmidt-Rhaesa (ed) Meiofauna. Pfeil Verlag

Remane A (1936) Monobryozoon ambulans n. gen., n. sp., ein eigenartiges Bryozoon des Meeressandes. Zool Anz 113:161-167

Remane A (1938) Ergänzende Mitteilungen über Monobryozoon ambulans Remane. Kieler Meeresforsch 2:356-359

Reverter-Gil O (2017) Familia Aethozoidae. En: IBERFAUNA. El Banco de Datos de la Fauna Ibérica. Museo Nacional de Ciencias Naturales (CSIC). Enlace: http://iberfauna.mncn.csic.es/showficha.aspx? rank $=$ J\&idtax $=6033$

Reverter-Gil O, Souto J, Fernández Pulpeiro E (2016) Fauna Iberica. Vol 43. Bryozoa 1. Ctenostomata. Museo Nacional de Ciencias Naturales, Madrid

Ruthensteiner B (2008) Soft part 3D visualization by serial sectioning and computer reconstruction. Zoosymposia 1:63-100

Schwaha T, Wanninger A (2018) Unity in diversity: a survey of muscular systems of ctenostome Gymnolaemata (Lophotrochozoa, Bryozoa). Front Zool 15: 24

Schwaha T, Wood TS, Wanninger A (2011) Myoanatomy and serotonergic nervous system of the ctenostome Hislopia malayensis: evolutionary trends in bodyplan patterning of Ectoprocta. Front Zool 8:11

Todd JA (2000) The central role of ctenostomes in bryozoan phylogeny. In: Herrera Cubilla A, Jackson JBC (eds) Proceedings of the 11th International Bryozoology Association Conference. Smithsonian Tropical Research Institute, Balboa, pp 104-135

Weber A, Wanninger A, Schwaha T (2014) The nervous system of Paludicella articulata - first evidence of a neuroepithelium in a ctenostome ectoproct. Front Zool 11:89

Publisher's note Springer Nature remains neutral with regard to jurisdictional claims in published maps and institutional affiliations. 